\title{
Transboundary Collaborations to Enhance Wildfire Suppression in Protected Areas of the Black Sea Region
}

\author{
G. N. Zaimes ${ }^{1 *}$, M. Tufekcioglu ${ }^{2}$, A. Tufekcioglu ${ }^{2}$, S. Zibtsev $^{3}$, R. Corobov ${ }^{4}$, D. Emmanouloudis ${ }^{1}$, R. \\ Uratu $^{5}$, A. Ghulijanyan ${ }^{6}$, A. Borsuk ${ }^{3}$ and I. Trombitsky ${ }^{4}$ \\ ${ }^{1}$ Eastern Macedonia and Thrace Institute of Technology, Dept. of Forestry and Natural Environment Management, Drama, Greece; \\ ${ }^{2}$ Artvin Coruh University, Artvin, Turkey; \\ ${ }^{3}$ National University of Life and Environmental Sciences of Ukraine, Kiev, Ukraine; \\ ${ }^{4}$ Eco-TIRAS International Association of River Keepers, Chisinau, Republic of Moldova \\ ${ }^{5}$ Prefect's Institution of Braila County, Braila, Romania; \\ ${ }^{6}$ Zikatar Environmental Centre, Ministry of Nature Protection, Republic of Armenia
}

Received 7 April 2016; Accepted 19 May 2016

\begin{abstract}
For the most effective and efficient management of certain natural resources (e.g. protected areas) and disasters (e.g. wildfires) transboundary approaches are needed. In addition in the management of protected areas, the role of wildfire should be incorporated, something that was ignored in the past and led to catastrophic wildfires. The Black Sea is a region that wildfires in the protected areas are expected to increase. This has to do with the abandonment of rural areas and the higher temperatures, especially during summer, due to climate change. Interesting is also the fact that some countries of the region have extensive experience while other do not have neither the experience nor the necessary infrastructures to face large wildfires. A transboundary collaboration would be very beneficial to the countries with limited experiences and capacities to suppress wildfires. The objective of this study is to be proactive by developing innovative tools to help suppress wildfires and enhancing the knowledge on wildfires and protected areas. The innovative tools included 4 different research activities and products. Firstly, an online Digital Geodatabase for the six pilot areas was developed. Next forest fire fuels and maps were developed while a forest fire behavior model was run to create the overall fire risk maps for the pilot areas. To estimate water resources and watershed streamflows the hydrologic model SWAT was validated and calibrated for the pilot areas. The final activities included a multi-criteria decision analysis to select the optimal location of the water reservoirs and the use of spatial analyst to provide the optimal routes to reach reservoirs by the fire vehicles. To enhance the responsible agency personnel along with stakeholders knowledge of the region, a Neighborhood Network with regular quarterly meetings was established. Participants for all six project countries were present in the meetings. Overall, new tool that will enhance wildfire suppression in protected area were developed while the awareness of wildfire danger and the importance of protected areas increased.
\end{abstract}

Keywords: climate change, wildfire risk, hydrologic resources, multi-criteria decision analysis, transnational network

\section{Introduction}

Natural ecosystems and disasters do not follow man-made boundaries [1]. This is a serious concern when trying to effectively and efficiently manage these areas or such disasters. In some cases, coordinated actions among riparian countries are required. Many efforts are made to address this issue, especially in Europe that has a large number of riparian countries relative to the land area it occupies. Specifically, the European Union (EU) is addressing this through the European Neighborhood and Partnership Instrument. Through this instrument the $\mathrm{EU}$ funds transnational project with partners from different countries (EU and non-EU) but from the same region to work together and implement projects. This allows riparian countries to

\footnotetext{
*E-mail address: zaimesgeorge@gmail.com ISSN: 1791-2377@ 2016 Eastern Macedonia and Thrace Institute of Technology. All rights reserved.
}

collaborate with each other that otherwise might likely not, since many of these countries do not always have very friendly and trusting relationships.

Protected areas are one of the most significant land-use designations by humans. This is evident since their establishment is the greatest land-use transformation at the end of the $20^{\text {th }}$ century [1]. Specifically, there are more than 100,000 protected sites that cover $12 \%$ of the earth terrestrial surface. Their purpose is to help sustain life on earth by protecting different and rich in biodiversity landscapes that provide many ecological services and goods and preserve the natural and cultural heritage [1]. In the European Union the ecological Natura 2000 network has been established [2] with the purpose to stop the decline in biodiversity. Currently, it protects more than 25,000 sites that cover approximately 80 million ha.

An important aspect that should always be considered when managing protected areas are wildfires $[3,4]$. There is a strong interconnection between protected areas and wildfires [1] that is not always recognized by land managers. 
In protected areas, the elimination of wildfires coupled with the minimal management actions can and has led to the accumulation of wildfire fuels and catastrophic wildfires. Such a wildfire occurred in Yellowstone National Park in the United States [5]. The extensive accumulations of fuels led to a crown wildfire that was more catastrophic than the typical ground wildfires. Future management plans of protected areas need to understand and incorporate the natural role of wildfires in order to be effective and efficient in the long term [6].

Wildfires are a natural phenomenon but human activities have accelerated the frequency and damages caused by it [7]. Forest fires are a major concern in many countries in Europe, especially in the Mediterranean Region, but are also becoming a major threat in the Black Sea region [8]. One of the main reasons for the increased wildfire activity in this region is the past changes in land-use and land-cover due to the geopolitical and economic changes in the early 1990-s [9]. The rural population has decreased because of their extensive movement to cities. Consequently, the lands under proper agriculture and forest management have also decreased and the abandoned areas, that typically are highly prone to wildfires, have increased.

Another important reason is the global climate change that will also impact wildfire frequency and magnitude [8]. Higher temperatures and longer drought periods due to climate change will lead to conditions that are more conductive to wildfires, especially large scale catastrophic wildfires [11]. The most current IPCC report [12] on climate change projected an increase in the occurrence of high wildfire danger days [13] and in wildfire season length in Europe [14].

While the Mediterranean part of Europe has extensive firefighting experience and capacity, the same cannot be said for the northeastern part of Europe. This region is not prepared properly for such large fires, since their wildfire capacity is limited. The region has also experienced anthropogenic activities for centuries that have heavily degraded protected areas while future large wildfires would substantially decrease them. Promoting wildfire management in the protected areas in the Black Sea region should be a priority and be based on the experiences of integrated fire management including the use of prescribed fire in forestry and conservation in temperate-boreal Eurasia $[15,16]$.

The main objective of this study was to promote research and innovation in the field of wild fire suppression and to enhance the protection of natural areas in the Black Sea region. To meet this objective two different type of activities were undertaken. Firstly, research activities utilizing new innovative technologies to enhance wildfire suppression preparedness were developed. Secondly, a neighborhood network was established to better inform agencies, stakeholders and the general public on the wildfire suppression and new innovative tool to suppress them.

\section{Partners and Pilot Areas}

A transboundary approach needed to be implemented to meet the objectives of the study. This required partners from all around the Black Sea region. Specifically, from the northern part of the Black Sea was the National University of Life and Environmental Sciences from Ukraine from the northwestern was Eco-TIRAS International Association of River Keepers from the Republic of Moldova, from the western the Prefect's Institution of Braila County from Romania, from the southwestern the lead partner, Eastern Macedonia and Thrace Institute of Technology from Greece, from the southern Artvin Coruh University from Turkey and from the eastern Zikatar Environmental Center from the Republic of Armenia (Figure 1). The selection of the partners was purposefully very diverse, with three universities providing a more scientific approach to the study along with a national organization, a local organization and non-governmental organization providing a more applied approach.

In addition, the objective was to have the study applicable to the entire Black Sea region. To accomplish a pilot area from each participating country was selected. This way ecosystems from all around the region were included. All six selected pilot areas have ecological importance because of their unique forest ecosystems that has led to their designation as protected. In addition, these areas have experienced wildfires issues particularly in the recent years. Menoikio Mountain is located in Northern Greece and belongs politically to the Region of Eastern Macedonia (Figure 2A). It covers approximately an area of 50,500 ha. The main species present are Quercus pubescens, Quercus coccifera, Castanea sativa and Fagus sylvatica. Most of Menoikio is in the Natura 2000 Network.From 1984-2009, 106 fires have been recorded that have burned 2208 ha. The Bayam Forest District is in Kastomonu, Turkey and has a total area of 16,006 ha out of which $80 \%$ is forested (Figure 2B). Major species include Pinus nigra, Quercus petraea, Quercus pubescens, Pinus sylvestris and Fagus orientalis. The remaining $20 \%$ is used for agricultural and hay production, and residential purposes. Fire is an important threat to these forests during the dry summer period. From 1963 to 2003, 101 fires occurred that burned 645 ha. The Ukrainian pilot area is Yalta Mountain Forest Natural Reserve (Figure 2C).It is located on the southern slope of the main ridge of the Crimean Mountains and occupies an area of 14,523 ha. Major species include Pinus nigra, Quercus petraea, Carpinus betulus, Fraxinus excelsior, Pinus kochiana, Pinus sylvestris, Juniperus excelsa, Juniperus oxycedrus and Fagus sylvatica. It was selected by WWF as one of the most important among other eight regions in Europe. From 1993-2006 a total of 2,120 forest fires have occurred that burned more than 2,170 ha of forests lands, including 258 ha burned from crown fires. The Arevik National Park is in southern Armenia, cover a total area of 34,402 ha and stands out because of its high biodiversity (Figure 2D). Major species present are Juniperus polycarpos, Juniperus oblonga, Quercus iberica, Quercus macranthera and Carpinus betulus It belongs to the Emerald Network that is an ecological network made up of "areas of special conservation interest." In this pilot area in the last 5 yrs, 200 ha have been burned. In Romania the Natural Park Small Wetland of Braila was selected (Figure 2E). It covers an area of 24,555 ha and has a triple protection status national (natural park), EU (Natura 2000 site) and international (RAMSAR site). The main species present include Salix alba, Salix cinerea, Salix fragilis, Populus alba, Populus nigra and Ulmus foliacea, Every spring the risk of fires increases because of the seed dispersal from the poplars (Populus spp.). Finally, the Codrii Reserve has the aim to conserve the most representative areas of forests, characteristic to the Central Plateau of Moldova (Figure 2F). Major species include Quercus petraea, Quercus robur, Fagus sylvatica and Carpinus betulus. It is separated in three zones: a) Strictly protected (720 ha) with no human activity, 
except scientific research; b) Buffer Zone (4,456 ha) that $\quad$ c) Transition (12,300 ha) a 2-km area around the buffer zone surrounds the previous one to limit the human impacts; and that includes mainly private or public agriculture lands.

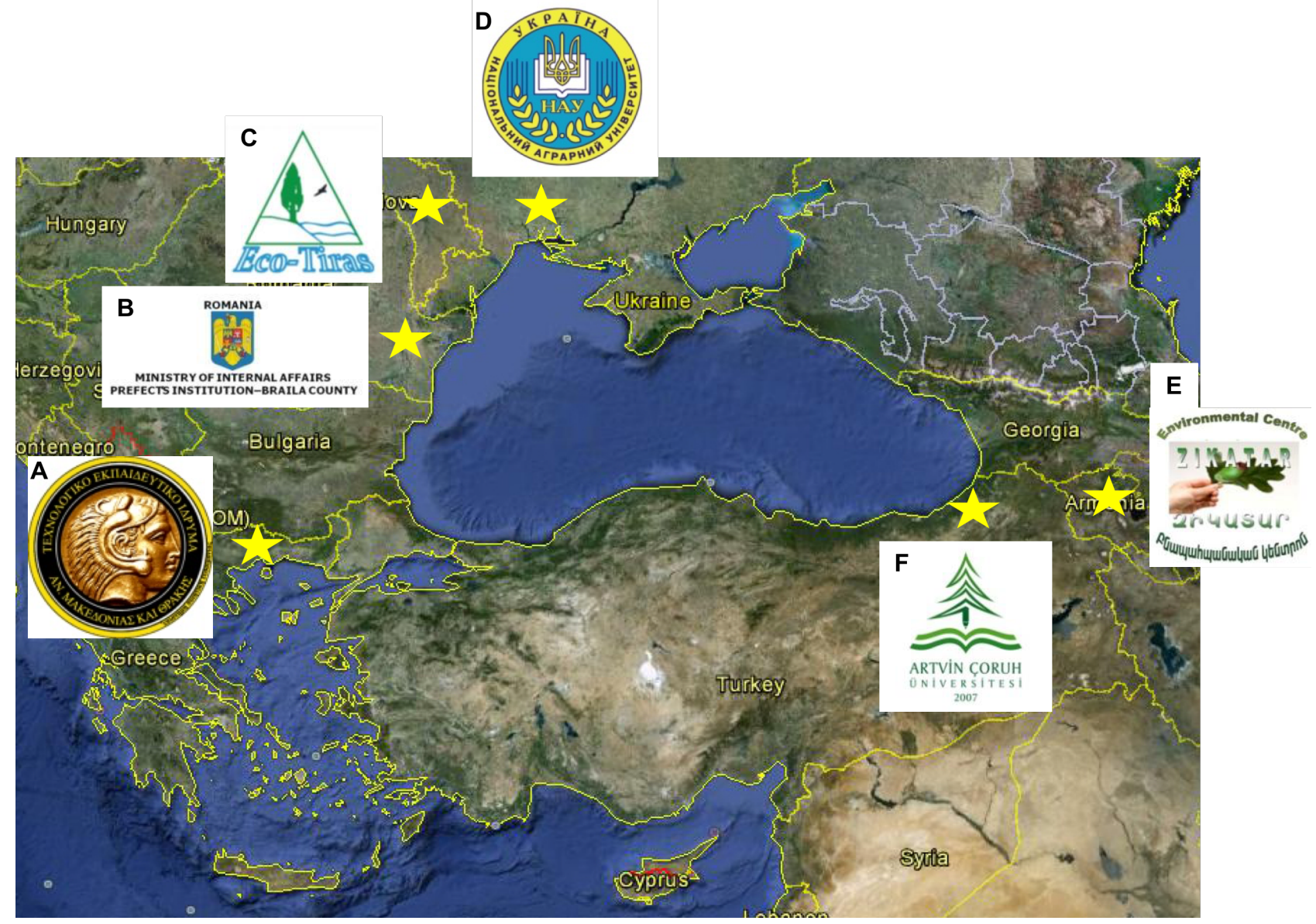

Fig. 1. The partners were from six different countries of the Black Sea region in order to implement a transboundary study. Specifically: A) Eastern Macedonia and Thrace Institute of Technology, Greece (lead partner), B) Prefect's Institution of Braila County, Romania, C) Eco-TIRAS International Association of River Keepers, Republic of Moldova, D) National University of Life and Environmental Sciences, Ukraine, E) Zikatar Environmental Center, Republic of Armenia and F) Artvin Coruh University, Turkey

\section{Research Activities}

Preparedness and pro-active management should be a priority in order to effectively and efficiently manage wildfire and minimize negative impacts [17]. This is why most countries have established special agencies that are responsible for their suppression (e.g. Fire Service, Forest Service, Emergency Services etc.) that have been successful at the national level. Through the research activities of this study new and innovative tools were developed applicable to all the pilot areas that could be utilized easy by the responsible agencies before and during wildfire events. The research activities focused on estimating for all six pilot areas: a) wildfire risk, b) potential water resource availability and c) optimal location of new reservoirs and routes to access to the reservoirs.

\subsection{Digital Geodatabase}

A key element for successful management is the availability of data of the area of interest, especially in electronic format. For this purpose spatial data for all the pilot areas were created. The spatial data collected were: topography, stream network, watershed boundaries, land-uses/land cover and soils. Currently the data are freely available as digital geodatabases at the following address: http://suppressfires.eu/index.php/geodatabase

\subsection{Estimating Wildfire Risk}

The accurate prediction of wildfire behavior is an important tool for agencies to mitigate them efficiently. To predict behavior it is necessary to primarily consider fuel parameters, weather conditions, and topography. The fire science community uses the term "fuels" to describe vegetation composition and structure [18]. Fuel models are simulated complexes of fuel elements with physical and chemical parameter values representative of the typical fuel conditions (combustible materials) of a certain vegetation type [19]. Through this project the fuel models for each pilot area were developed by field surveys using standard inventory surface fuel biomass methods [20]. Specifically, the areas were stratified dominant based on the vegetation type and 11 fuel parameters were measured. 

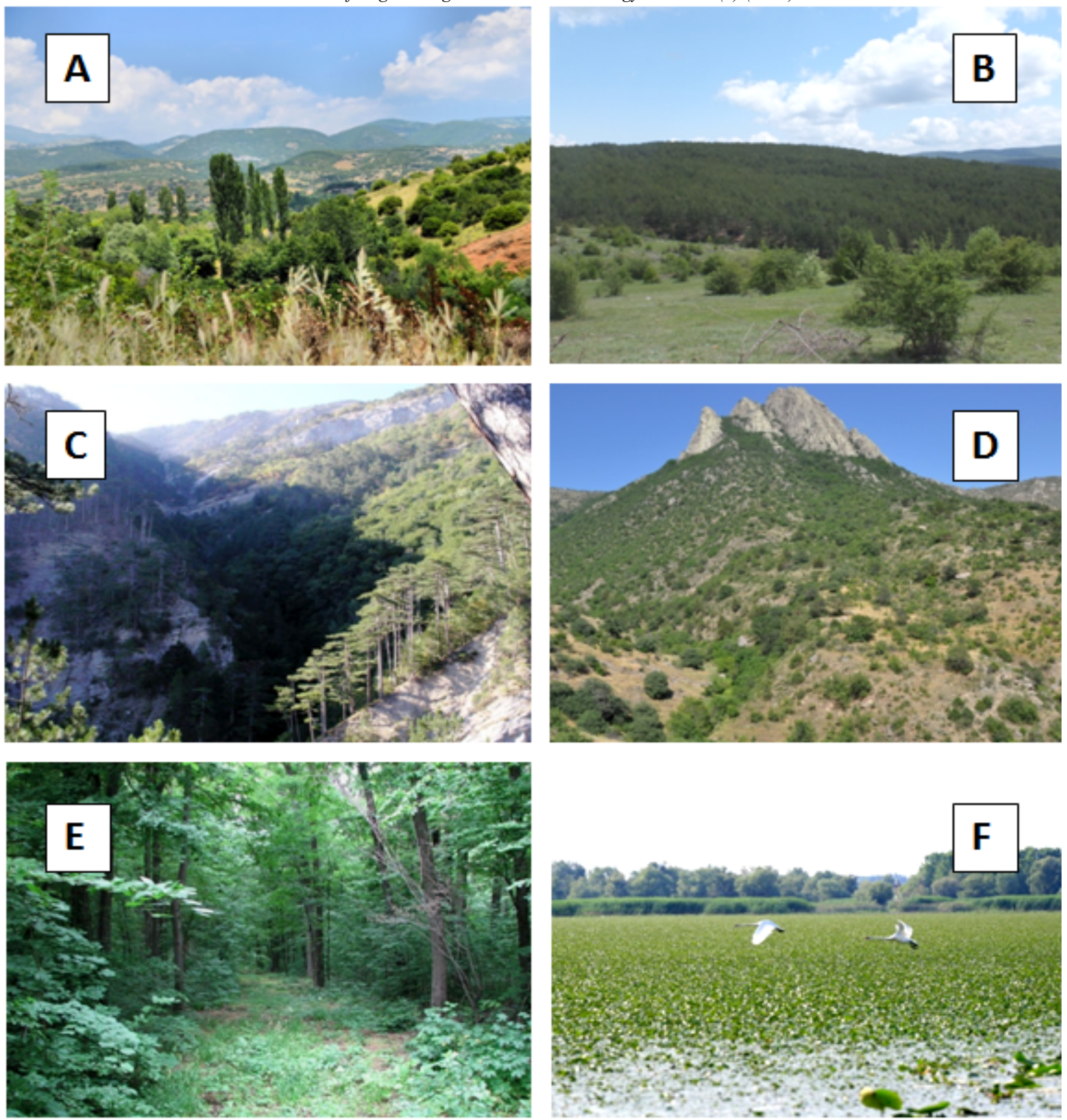

Fig. 2. Six pilot areas from different parts of the Black Sea region were selected: A) the Menoikio Mountain, Greece, B) the Bayam Forest District, Turkey, C) the Yalta Mountain Forest Natural Reserve, Ukraine, D) the Arevik National Park, Republic of Armenia, E) the Codrii Reserve, Republic of Moldova and F) the Natural Park Small Wetland of Braila, Romania

Based on the fuel models, fuel maps using remote sensing techniques were developed [21, 22]. Indices were developed based on satellite images and to differentiate vegetation types the object based image analysis and classification and regression trees were implemented. In wildfire management landscape-level fuel maps provide the information for fire behavior and growth models that are used to simulate wildfire and wildfire effects assessment strategies. In this project, maps of the fuel types for all six pilot areas were generated (Figure 3A).

Finally, wildfire risk maps for each pilot area were developed using the specialized software, specifically FlamMap version 5 (Figure 3B). FlamMap computes potential wildfire behavior characteristics (spread rate, flame length, fire line intensity, etc.) over an entire landscape for constant weather and fuel moisture conditions [23]. It utilizes the MTT algorithm to replicates fire behavior that is based on the Huygen's principle. The main data necessary for the simulation were the: Digital Terrain Model of the area, wind directions and speed, the spatial extent fuel models (fuel map) and the fuel parameter values (fuel types).

The knowledge on the spatial extent of the fuels, and their potential fire behaviors allows national authorities and fire managers to improve the design of fire prevention measures, detection, suppression, and is an important tool to mitigate wildfires.

\subsection{Estimating Watershed Streamflows}

Water is essential for the efficient and effective wildfire suppression management. This is especially true for land vehicles during bight time when helicopters and airplanes cannot be used. This is the reason why an emphasis was given on estimating the water resources available in the pilot areas. Another important part was also the sustainable use of the water resources [24] from the streams of the pilot areas. To accomplish this a hydrologic model was used. 
Hydrologic models are useful tools for the effective and efficient water management.

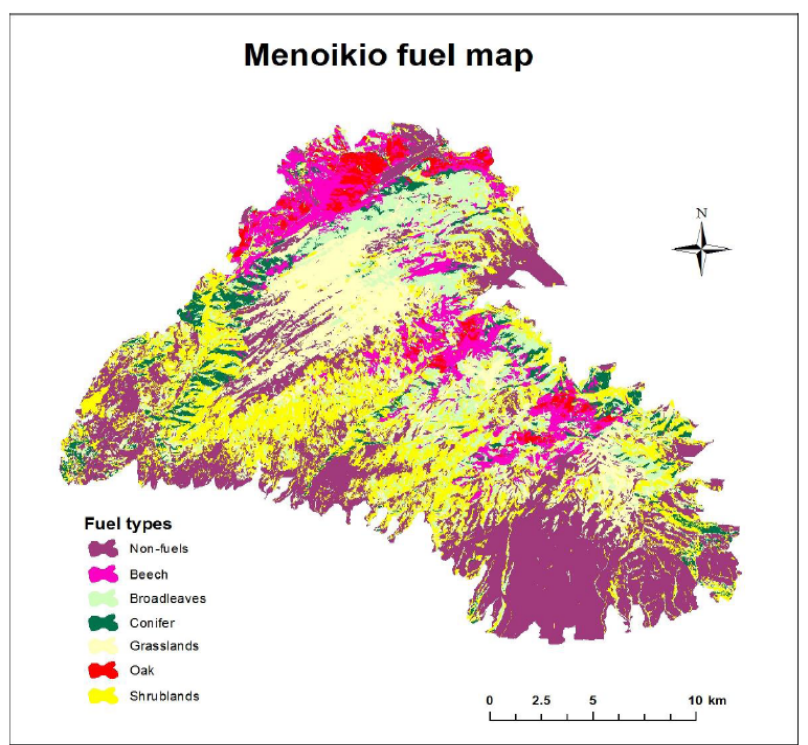

A)

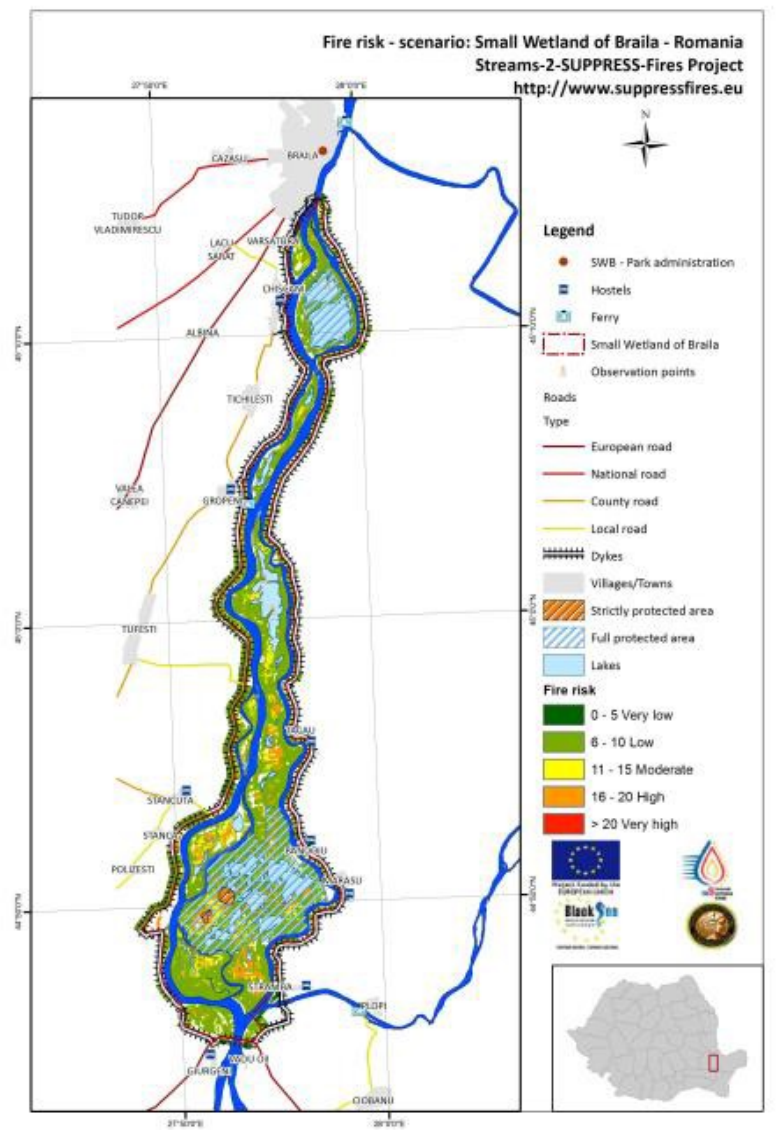

B)

Fig. 3. Wildfire suppression tools were developed for all six pilot areas. A) The Forest Fuel Model Map for Menoikio Mountain (map developed by Georgios Mallinis). The fuel model categories were: i) litter layer of beech forests, ii) litter layer of oak forests, iii) and the litter layers of conifer forests, iv) evergreen schelophyllous shurblands v) grassland and vi) litter layer of broadleaved forests. B) The Overall Wildfire Risk Map based on the FlapMap (map developed by Ionut Sandric). Risk FlapMap (map developed by Ionut Sandric). Risk was categorized in the following categories: i) Very Low, ii) Low, iii) Moderate, iv) High and v) Very High
Specifically, SWAT, the Soil and Water Assessment Tool hydrologic model was used to estimate the potential stream water resources. This is a physically based model, that computes discharge from readily available data (e.g. weather, soil, vegetation, land management practices), and allows the study of short to long-term impacts, processing data on a continuous time mode [25]. SWAT simulates the hydrology, using a water balance equation that allows the estimation of the water budget (Figure 4) and the potential streamflow at the watershed scale. In this study ArcSWAT was used, which is the GIS interface for SWAT. ArcSWAT requires information about the topography, soils, land-uses, slope categories and weather data from the study region [26]. Actual streamflow data were collected to calibrate and validate the SWAT model for each pilot area. The final products were maps of the six pilot areas that show the streamflow of their watersheds (Figure 5). Streamflow was categorized in the following categories: i) Very Low, ii) Low, iii) Moderate, iv) High and v) Very High.

These maps could be used by land and water managers to sustainably utilize the water resources for a number of different purposes including wildfire suppression.

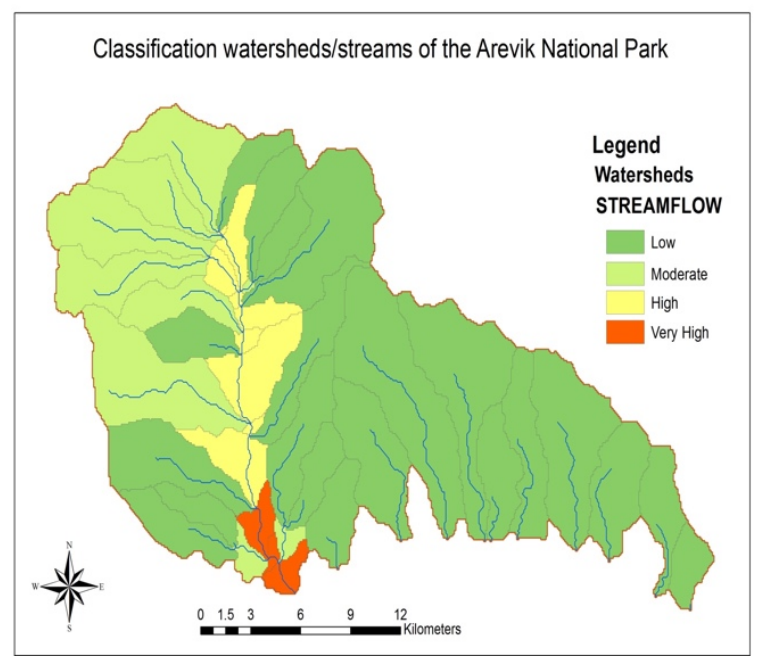

Fig. 5. The average streamflow of for the main stream of the Arevik National Park, in the Armenian pilot area. The streamflows are divided into four categories: i) Low, ii) Moderate, iii) High and v) Very High.

\section{Water Balance}

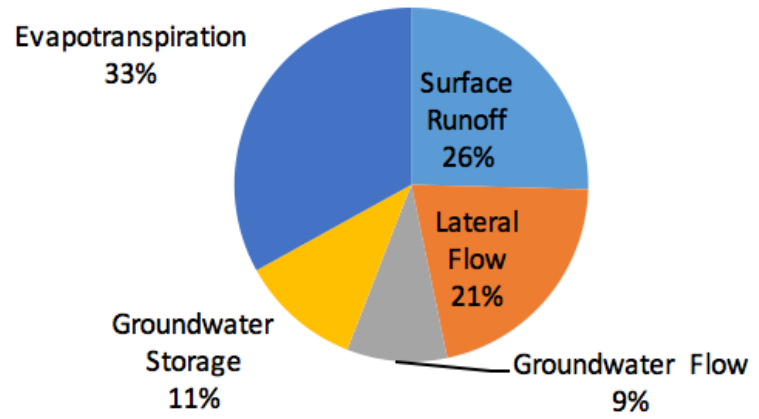

Fig. 4. The water balance, as estimated Yalta Forest, the Ukrainian pilot area, using the SWAT model. The climate time-series used were for 2001-2015. The components of the water budget were: i) evapotranspiration, ii) groundwater storage, iii) groundwater flow, iv) lateral flow and v) surface runoff. 


\subsection{Estimating the Reservoir Optimal Locations and Routes}

To estimate the optimal location of the water reservoirs a Multi-Decision Criteria Analysis (MCDA) coupled with GIS was conducted. The MCDA is a formalized method that facilitates knowledge mining and its translation into a computer language, by typically assigning weights for the most influential factors [27].

This method is widely used for environmental problems that are influenced by many criteria [28]. The criteria used for the optimal reservoir locations were the following: a) distance from roads, b) distance from streams, c) land-uses, d) aspect, e) slope, f) accessibility. These criteria were imported in the specialized software and the proper goal was set to the calculation of the optimal reservoir locations.

Afterwards the selected criteria were evaluated by using the Saaty scale [29]. This scale compares each criterion with another (pairwise comparison) and a number is given to this comparison based on the level of significance of the comparison. Once comparisons are finished, the weight coefficients are calculated.

The map of each criteria in combination with the calculated weight coefficients create the final maps based on a mathematical formula that was specific for each pilot area. The final map created indicates the optimal locations that the reservoirs should be constructed. For the final selection of the reservoirs locations, a field survey of the suitability (e,g, soil and slope suitability) of the proposed locations was done (Figure 6).

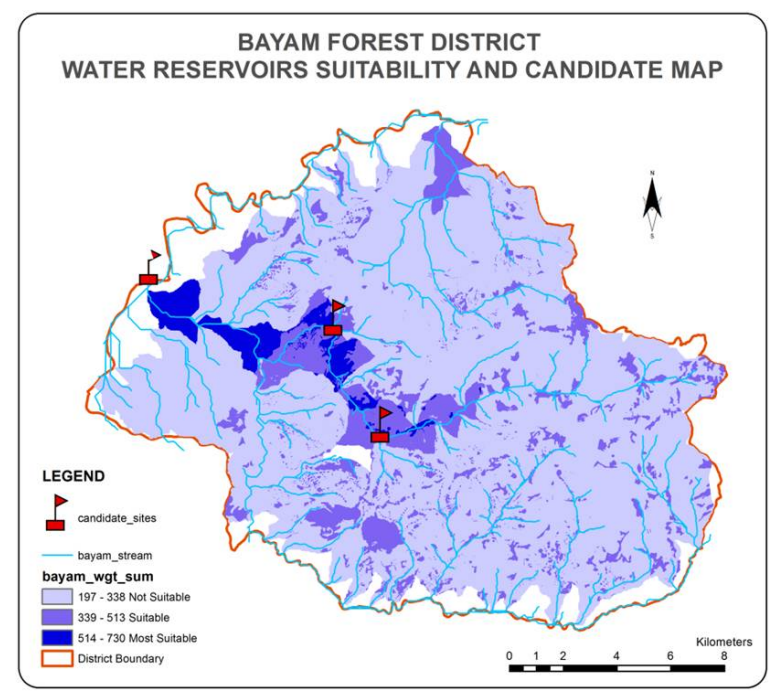

Fig. 6. The optimal locations (red flags) for Bayam Forest, the Turkish pilot area. For this pilot area three reservoirs were proposed to be constructed.

For the optimal routes to the proposed reservoirs, GIS with Spatial Analyst was used. This was accomplish by first determining the entry point for the fire fighting vehicles. The entry points determine the junctions the vehicles pass when the approach the study area. An important restriction to determine the optimal route was the fact that the vehicles cannot move through roads with slopes greater than $10 \%$. So this was a restriction that was incorporated in order to avoid these roads. Afterwards the shortest path methodology was applied to determine the optimal routes to reach the proposed reservoir locations for each pilot area.

\section{Neighborhood Network}

Enhancing awareness is very important for this region taking into consideration that the majority of wildfires in the region are due to human activities [8]. The objective was to educated and inform a great variety of people. Specifically, direct beneficiaries that were public administrations and their institutions that are responsible for wildfire management, and/or the management of natural protected areas. In addition we were interested in reaching the indirect beneficiaries that are all stakeholders and general public that have an interest in the more effective management of protected areas and wildfire suppression. Additionally, many natural resources including protected areas are transboundary that means effective and efficient management requires transnational collaboration. Transnational planning can help better mitigate disasters (e.g. wildfires) that are common for an entire region. These were the reasons for the establishment of the Neighborhood Network.

The Network provided a forum where the potential collaborators can meet and discuss their problems and concerns. Through this forum professionals in the field of wildfire suppression and protected areas of the Black Sea region could learn new tools, exchange experiences, provide support to each other etc. These meeting could also be attended by stakeholders and the general public.

Two national and five Black Sea regions meetings were conducted for a total of seven meetings. Prior to the meetings informative invitation letters were sent to the leading institutions in the sphere of forestry, forest fires, protected areas, fire prevention and suppression, water management and management of protected areas. These institutions were requested to appoint their relevant staff as a member of Neighborhood Network.

The $1^{\text {st }}$ and $4^{\text {th }}$ Neighborhood Network meetings were at the national level and held in the summers of 2013 and 2014, respectively, in each partner country. During the $4^{\text {th }}$ National Neighborhood Network meeting the Digital Geodatabase was introduced and evaluated.

The other five meetings were online using the software Acrobat Connect with participants from all Black Sea partner countries. In each meeting more that 75 people participated. The $2^{\text {nd }}$ Neighborhood Network was held on December $11^{\text {th }} 2013$ and focused on the wildfires of the past summer and the current conditions of the protected areas in each country. In the $3^{\text {rd }}$ Neighborhood Network that was held on March $19^{\text {th }} 2014$ government employees described how wildfire were suppressed in the countries. During the $5^{\text {th }}$ Neighborhood Network that was held on December $17^{\text {th }}$ 2014, the focus of the meeting was the implementation of hydrologic model is each of the six partner countries. The $6^{\text {th }}$ meeting was held on May $20^{\text {th }} 2015$ with partners presenting part of their results. The final meeting (7th) meeting was held on November $4^{\text {th }} 2015$. During this meeting the final results of the project by each partner were presented. Afterwards the participants were asked to express their opinions on the tools developed and also provide recommendations on the next steps to improve wildfire suppression and management of the protected areas.

\section{Conclusions}

Wildfire frequency and intensities are expected to increase in general but also in the protected areas of the Black Sea 
region because of the climate change impacts and the region's geopolitical and economic changes. A holistic approach for the effective and efficient management of wildfire suppression, especially in protected areas is a necessity. A number of research activities were implemented to accomplish this. The geodatabase provides agencies and stakeholders with freely available data that enhance the management effectiveness and awareness of pilot protected areas. The development of fuel type and fire risk maps that did not previously exist in the pilots areas have greatly enhanced the firefighting capacity of the responsible authorities. The calibrated hydrologic model provided greater insight on the water budget of the pilot areas and along with MCDA helped find the optimal locations for new water reservoirs. Finally, the neighbourhood network. Finally, the neighbourhood networking in the Black Sea Region has contributed to establish cross-boundary relationships and cooperation in fire management promoted the awareness of wildfires and protected areas to the agencies, stakeholders and general public in the region. This was important since human activities are the number one cause of wildfires in the region. With the termination of the project it is recommended that the neighbourhood cooperation be continued under the aegis of the UNISDR
Regional Eurasia and Southeast Europe / Caucasus Wildland Fire Networks, facilitated by the Regional Fire Monitoring Centers for Southeast Europe / Caucasus and for Eastern Europe [30, 31].

This paper was presented at International Conference titled "Frontiers in Environmental and Water Management", that took place March 19-21st 2015, at Kavala Greece.

\section{Acknowledgements}

The EU INTERREG IV "Black Sea Basin Joint Operational Programme 2007-2013" framework is responsible for the funding of this project. The Black Sea Basin Programme is co-financed by the European Union through the European Neighborhood and Partnership Instrument and the Instrument for Pre-Accession Assistance. This document has been produced with the financial assistance of the European Union. The content of this document are the sole responsibility of the authors and can under no circumstances be regarded as reflecting the position of the European Union.
1. M. Lockwood, A. Kothari, G. Worboys (eds.), Managing Protected Areas: a Global Guide, Earthscan, London (2006)

2. European Commission, Natura 2000 network at http:/ec.europa.eu/environment/nature/natura2000/

3. E. Beltran, O. Byambasuren, I. Mitsopoulos, J.G. Goldammer. Proc. Int. Wildfire Conf., Pyeongchang, Republic of Korea (2015)

4. G. Mallinis, I. Mitsopoulos, E. Beltran, J.G. Goldammer, Forests 716, 7 (2016)

5. W.H. Romme, H.G. Despain, BioScience 39, 696 (1989)

6. G.N. Zaimes, M. Tufekcioglu, A. Tufekcioglu, S. Zibtsev, D. Kaziolas, M. Yavuz, I.Trombitsky, D. Emmanouloudis, R. Uratu, A. Ghulijanyan, A. Borsuk. Proc. Int. Caucasian Forestry Symposium, Artvin, Turkey. pp. 345-353 (2014)

7. L.F. DeBano, J Hydrol. 231, 195 (2000)

8. S. Zibtsev, I. Mitsopoulos, G. Mallinis, B. Saglam, A. Borsuk, G. N. Zaimes, M. Yavuz, D. Galupa, D. Emmanouloudis, R. Uratu, R. Moisei, A. Ghulijanyan, Earth Bioresources and Life Quality (Electronic Journal) (2013)

9. J. Goldammer, V. Furyaev, Fire in ecosystems of boreal Eurasia. Kluwer, Hague, Netherlands (1996)

10. P.S. Lake, Drought and Aquatic Ecosystems: Effects and Responses. John Wiley \& Sons, Chichester, UK (2011)

11. J. Hansen, M. Sato, R. Ruedy Proc. Nat. Acad. Sci. 109, E2415 (2012)

12. R.S. Kovats, R. Valentini, L.M. Bouwer, E. Georgopoulou, D. Jacob, E. Martin, M. Rounsevell, and J.-F. Soussana, Impacts, Adaptation, and Vulnerability. Part B: Regional Aspects. Contribution of Working Group II to the Fifth Assessment Report of the Intergovernmental Panel on Climate Change, Cambridge University Press, Cambridge, UK, pp. 1267-1326 (2014)T. Lung, R. Lavalle, A. Hiederer, L. Bouwer. Global Environ. Change 23: 522-536 (2002)G. Pellizzaro, A. Ventura, B. Arca, A. Arca, P. Duce, V. Bacciu, and D. Spano, In Proc. Int. Forest Fire Res. Conf., Coimbra, Portugal, pp. 123. (2010)

13. http://www.fire.uni-freiburg.de/programmes/natcon/natcon.htm

14. J.G. Goldammer, (ed.) A publication of the Global Fire Monitoring Center (GFMC). Kessel Publishing House, Remagen, Germany 281-313, (2015)

15. C.T. Fowler, J. Ecol. Anthropol. 7, 39 (2003)

\section{References}

16. A. P. Dimitrakopoulos, Int. J. Wildland Fire 11, 127 (2002)

17. H. Anderson, Aids to determining fuel models for estimating fire behavior. USDA Forest Service Intermountain Research Station, Ogden, USA (1982)

18. J. Brown, R. Oberheu, C. Johnston. 1982. Handbook for inventorying surface fuels and biomass in the Interior West. USDA Forest Service, Intermountain Forest and Range Experiment Station, Ogden, USA (1982)

19. R. Keane, R. Burgan, J. Wagtendonk, Int. J. Wildland Fire 10, 301 (2001)

20. M. Yavuz, B. Saglam, KSU J. Engin. Sci. 235, (2012)

21. M.A. Finney, Fuels Management - How to measure success: Conference Proceedings. p 213-219 (2006)

22. G.N. Zaimes G.N., D. Emmanouloudis. J. Eng. Sci. Tech. Rev., 5, 77 (2012)

23. S.L. Neitsch, J.G. Arnold, J.R. Kiniry, J.R. Williams, K.W. King (2011) Soil and Water Assessment Tool-Theoretical Documentation-Version 2009. Grassland, Soil and Water Research Laboratory, Agricultural Research Service and Blackland Research Center, Texas Agricultural Experiment Station, Temple, USA, (2011)

24. M. Winchell, R. Srinivasan, M. Ri-Luzio, J.G. Arnold, ArcSWAT Interface for SWAT 2009: User's Guide. Texas Agricultural Experiment Station and USDA Agricultural Research Service, Temple, USA (2013)

25. J. Malczewski, GIS and Multicriteria Decision Analysis John Wiley \& Sons, New York, USA (1999)

26. G.N. Zaimes, D. Gounaridis, V. Iakovoglou, D. Emmanouloudis. Assessing soil erosion risk for Rhodes Island, Greece with a GIS-based multi-criteria decision analysis. Proc. IASTED Int. Conf. Water Resour. Manage. Gaborone, Botswana (2012)

27. T.L. Saaty, J. Math. Psych. 15, 234 (1977)

28. T.L. Saaty, The Analytic Hierarchy Process McGraw-Hill, New York, USA (1980)

29. http://www.fire.unifreiburg.de/GlobalNetworks/SEEurope/SEEurope.html

30. http://www.fire.unifreiburg.de/GlobalNetworks/BalticRegion/BalticRegion.html 